University of Nebraska - Lincoln

DigitalCommons@University of Nebraska - Lincoln

\title{
Comparison of two soil quality indexes to evaluate cropping systems in northern Colorado
}

\author{
T.M. Zobeck \\ USDA-ARS, ted.zobeck@ars.usda.gov
}

\author{
A.D. Halvorson \\ USDA-ARS \\ Brian J. Wienhold \\ University of Nebraska-Lincoln, Brian.Wienhold@ars.usda.gov \\ V. Acosta-Martinez \\ USDA-ARS, veronica.acosta-martinez@ars.usda.gov \\ D. L. Karlen \\ USDA-ARS, doug.karlen@ars.usda.gov
}

Follow this and additional works at: https://digitalcommons.unl.edu/usdaarsfacpub

Zobeck, T.M.; Halvorson, A.D.; Wienhold, Brian J.; Acosta-Martinez, V.; and Karlen, D. L., "Comparison of two soil quality indexes to evaluate cropping systems in northern Colorado" (2008). Publications from USDA-ARS / UNL Faculty. 1201.

https://digitalcommons.unl.edu/usdaarsfacpub/1201

This Article is brought to you for free and open access by the U.S. Department of Agriculture: Agricultural Research Service, Lincoln, Nebraska at DigitalCommons@University of Nebraska - Lincoln. It has been accepted for inclusion in Publications from USDA-ARS / UNL Faculty by an authorized administrator of DigitalCommons@University of Nebraska - Lincoln. 


\section{Comparison of two soil quality indexes to evaluate cropping systems in northern Colorado}

\author{
T.M. Zobeck, A.D. Halvorson, B. Wienhold, V. Acosta-Martinez, and D.L. Karlen
}

\begin{abstract}
Various soil management or quality assessment tools have been proposed to evaluate the effects of land management practices on soil, air, and water resources. Two of them are the Soil Management Assessment Framework and the Soil Conditioning Index (SCI). This study was conducted to test the hypothesis that the Soil Quality Index (SQI) estimated by the Soil Management Assessment Framework can detect more minute changes in soil management than SCI and to test SCI response to other soil quality (SQ) indicators. These SQ indexes were tested on irrigated cropping systems near Fort Collins, Colorado, that included no-till and conventionally-tilled corn (Zea mays L.), and no-till corn with rotations including barley (Hordeum distichon L.), soybean (Glycine max (L.) Merr.), and dry bean (Phaeseolus vulgaris L.) at three levels of nitrogen varying from 0 to $224 \mathrm{~kg} \mathrm{~N} \mathrm{ha}^{-1}\left(0\right.$ to $\left.200 \mathrm{lb} \mathrm{ac}^{-1}\right)$. Both SQ indexes clearly separated the plots with very high levels of $\mathrm{N}$ from plots with no N. However, for SQI the mid-level of $\mathrm{N}$ was statistically the same as both extreme levels. Statistical differences were observed among all N levels for the SCI.The SQI seemed to make more detailed differentiation among crop management systems than the SCI. The SCI separated the cropping systems into three groups with no overlap among groups. All no-till systems had the statistically same higher SCI than the conventionally-tilled continual corn system. The SQI separated the cropping systems into three groups with decreasing SQI as tillage intensity increased and as lower residue crops were introduced into the cropping system. The systems that included tillage and a low residue crop (soybean) had the lowest SQI. The SQI allowed overlap among cropping groups not recognized by SCI. Selection of the most appropriate SQ index seems to be a tradeoff between data requirements, resolution required, and the desired use of the evaluation tool.
\end{abstract}

Key words: organic matter-Soil Conditioning Index (SCI)-soil management- Soil Management Assessment Framework (SMAF)—Soil Quality Index (SQI)—tillage

\begin{abstract}
Various soil management assessment tools have been proposed to evaluate the effects of land management practices on soil, air, and water resources. The capacity of the soil to function for specific purposes has been called soil quality (SQ) (Karlen et al. 1997). The appropriate SQ assessment tool measures changes in soil function in response to management within the context of the soil use (Andrews et al. 2004). For example, a soil that functions very well for crop growth may function very poorly for waste treatment. There has been some concern in using the term 'soil quality' in soil science (Sojka and Upchurch 1999), and tools and methods to assess and monitor SQ
\end{abstract}

are needed (Karlen et al. 2006). In this context, soil properties are usually used as indicators of SQ.

TheUSDANaturalResourcesConservation Service (NRCS) has adopted a SQ assessment tool called the Soil Conditioning Index (SCI) to estimate the effects of crop management on soil organic matter (also called soil organic carbon, SOC) (USDA NRCS 2002). The SCI was not designed to determine the current SOC level but to assess whether or not SOC levels would increase, decrease, or remain stable under the current cropping system. Determination of the SCI is required by several USDA NRCS criteria of practice standards, including the Conservation Crop

Rotation Practice Standard 328, and as an additional criteria in the Residue and Tillage Management-No Till/Strip Till/Direct Seed Practice Standard 329, and is specified for use in the Conservation Security Program of the Farm Security and Rural Investment Act of 2002.

The SCI estimates qualitative changes in SOC in the top $10 \mathrm{~cm}$ (4 in) of soils based on the combined and weighted effects of three determinants of organic matter using the following empirical equation:

$$
\begin{aligned}
& \mathrm{SCI}=[\mathrm{OM} \times(0.4)]+[\mathrm{FO} \times(0.4)]+ \\
& {[\mathrm{ER} \times(0.2)],}
\end{aligned}
$$

where OM represents the effects of organic material from animal or plant sources produced and returned to the soil, FO signifies effects of field operations including tillage and other field procedures, and ER corresponds to the influences of wind and water erosion (USDA NRCS 2003). Note that OM and FO in equation 1 each account for $40 \%$ of the final SCI value (total of $80 \%$ combined), and wind and water erosion represent $20 \%$. The SCI assumes that field operations reduce SOC by stimulating decomposition and that maintaining organic residues will maintain and increase soil organic matter levels. The amount of reduction of SOC due to field operations and erosion depends on the native level of carbon that may be sustained for a given site and region. The SCI is usually determined using a soil erosion model called the Revised Universal Soil Loss Equation (RUSLE2) (USDA NRCS 2003).

The Soil Management Assessment Framework (SMAF) is a relatively new SQ assessment tool based on the effects of management practices on dynamic soil properties and overall soil function (Andrews et al.2002; Andrews et al. 2004; Karlen et al. 2006). To develop a SQ index value, SMAF applies

Ted M. Zobeck is a research soil scientist at the Cropping Systems Research Lab, USDA Agricultural Research Service (ARS), Lubbock, Texas. Ardell D. Halvorson is a research soil scientist at the USDA ARS, Fort Collins, Colorado. Brian Wienhold is a supervisory research soil scientist at the Agroecosystem Management Research Unit, USDAARS, University of Nebraska, Lincoln, Nebraska. Veronica Acosta-Martinez is a research soil scientist at the Cropping Systems Research Lab, USDA ARS. Douglas L. Karlen is a supervisory research soil scientist at the National Soil Tilth Lab, USDA ARS, Ames, lowa. 
soil laboratory or field data for a minimum set of soil properties (called SQ indicators in SMAF) to scoring curves that indicate the potential of the soil to function for specific purposes. The SQ scoring curves vary from 0 to 1 , and a score of 1 represents the highest potential function and that the indicator is non-limiting to pertinent soil functions and processes (Andrews et al. 2004). Cropping systems are evaluated using a group of SQ indicators that represent the properties and processes that have the greatest sensitivity to the soil function under consideration. After all of the individual indicators used to assess a particular soil management system have been scored, they are combined into a final index; in this study we call it the Soil Quality Index (SQI). The SMAF has been tested in a wide variety of locations including Georgia, Iowa, California, and the Pacific Northwest (Andrews et al. 2002; Andrews et al. 2004), Iowa and Wisconsin (Karlen et al. 2006), and the Great Plains of the US (Wienhold et al. 2006).

Analysis of SQ using SMAF requires an interpretation step to evaluate specific soil properties (indicators) by comparing measured values to nonlinear scoring curves as described above (Andrews et al. 2004). In an analysis of several case studies, Andrews et al. (2004) found four general patterns of results when comparing scored and observed soil properties among treatments (such as between tillage versus no tillage) using ANOVAs. Pattern 1 was characterized by similar results for the scored and observed patterns. The second pattern found observed and scored values had opposite results. For example, the highest observed treatment value was found to have the lowest value after scoring. In pattern 3, the observed soil property results had significant differences among treatments, but the scored results showed no significant differences among treatments. The least common pattern, pattern 4 , had no significant differences among treatments for the observed results, but the scored values were significantly different among treatments.

Although the SCI has been proposed as a tool to assess the effects of soil management on SOC and is widely used by USDA NRCS, its effectiveness in assessing other resource concerns has not been adequately addressed. In addition, few tests of the ability of SCI to adequately describe the state of SOC have been performed, and the results obtained are conflicting. An evaluation of SCI using nine long-term $\mathrm{C}$ studies showed that positive trends in $\mathrm{C}$ followed positive trends in SCI, and negative SCI trends were associated with negative $\mathrm{C}$ trends (Hubbs et al. 2002). However, a recent study of 52 sites in west Texas (Zobeck et al. 2007) found that the SCI values were not strongly correlated with total SOC. The SCI values were more strongly associated with a specific and more labile form of SOC called particulate organic matter carbon (POMC). This study was conducted to test the hypothesis that the SMAF SQI can detect smaller differences among crop management systems than SCI and to test SCI response to other SQ indicators.

\section{Materials and Methods}

Study Site. This study was initiated in 1999 at the Agricultural Research and Development and Education Center $\left(40^{\circ} 39^{\prime} 6 " \mathrm{~N}\right.$, $\left.104^{\circ} 59^{\prime} 57^{\prime \prime W}\right)(1,555 \mathrm{~m}$ [5,100 ft] above sea level) near Fort Collins, Colorado, in a field that had been conventionally tilled (CT) and in continual corn production for six years before this study was started. The soil was a Fort Collins clay loam (fine-loamy, mixed, mesic Aridic Haplustalfs) with $330 \mathrm{~g}$ $\mathrm{kg}^{-1}(33 \%)$ clay and $410 \mathrm{~g} \mathrm{~kg}^{-1}$ (41\%) sand. The experiment had a randomized complete block design, with three replications, testing three $\mathrm{N}$ rates within each of five different cropping systems, including CT and no-tillage (NT) tillage systems. This study is part of a larger study of $\mathrm{N}$ and tillage effects on cropping systems (Halvorson and Reule 2006; Halvorson and Reule 2007; Halvorson et al. 2006; Mosier et al. 2006). The plot size was 10.7 by $15.2 \mathrm{~m}$ (35 by $50 \mathrm{ft}$ ). Unless stated otherwise, the average values listed in this paper refer to data collected annually throughout the five-year study period 2002 to 2006 , inclusive.

The five cropping systems included CT continual corn (Zea mays L.) (CTCC); notillage continual corn (NTCC); a no-tillage corn-barley (Hordeum distichon L.) rotation (NTCB); a no-tillage corn-soybean (Glycine $\max (\mathrm{L}$.) Merr.) rotation that was changed to a no-tillage corn-dry bean (Phaeseolus vulgaris L.) rotation (NTCS/D) in 2005; and a no-tillage corn-soybean-barley rotation (NTCSB). Corn, barley, soybean, and dry bean were directly planted into the previous year's crop without any tillage for seedbed preparation in the NT systems.
The corn, barley, soybean, and dry bean crops were sprinkler irrigated with a linearmove system as needed during the growing season each year. The amount of irrigation water applied varied with crop (Halvorson et al. 2006; Halvorson and Reule 2006, 2007). The average total annual precipitation during the May through September growing season was $148 \mathrm{~mm}$ (6 in), and varied from a low of $64 \mathrm{~mm}$ (2.5 in) in 2006 to a high of $181 \mathrm{~mm}$ (7.1 in) in 2004. The average irrigation water applied was $402 \mathrm{~mm}$ (15.8 in) for corn, 195 $\mathrm{mm}$ (7.7 in) for barley, $374 \mathrm{~mm}$ (14.7 in) for soybean, and $299 \mathrm{~mm}$ (11.8 in) for dry bean. Additional details of the tillage sequence, crops grown, and other cultural practices are described in Halvorson and Reule (2006, 2007) and Halvorson et al. (2006).

The three $\mathrm{N}$ rates used depended upon the crop and year. For corn production, the $\mathrm{N}$ rates were 0,67 , and $202 \mathrm{~kg} \mathrm{ha}^{-1}(0,60$, and $180 \mathrm{lb} \mathrm{ac}^{-1}$ ) for levels N1, N2, and N3, respectively, in 2002. The N3 application rate was $224 \mathrm{~kg} \mathrm{ha}^{-1}\left(200 \mathrm{lb} \mathrm{ac}^{-1}\right)$ in 2003 and 2004, and then increased to $246 \mathrm{~kg}$ $\mathrm{ha}^{-1}\left(220 \mathrm{lb} \mathrm{ac}^{-1}\right)$ in 2005 and 2006 to assure adequate $\mathrm{N}$ was available to maximize grain yields based on NT corn yields reported by Halvorson et al. (2006). For soybean and dry bean production in 2003 and 2005, the $\mathrm{N}$ rates were 0,22 , and $56 \mathrm{~kg} \mathrm{ha}^{-1}(0,20$, and $50 \mathrm{lb} \mathrm{ac}^{-1}$ ) for N1, N2, and N3 treatments, respectively. The $\mathrm{N}$ rates for barley were 0,45 , and $112 \mathrm{~kg} \mathrm{ha}^{-1}(0,40$, and 100

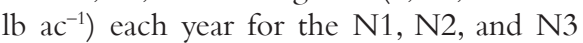
treatments, respectively, when barley was grown in the rotations in 2003 and 2005. These $\mathrm{N}$ rates were applied to the same plots ( $\mathrm{N}$ treatments) each year, depending on the crop grown.

Grain yields generally were determined in mid-July (barley), mid-September (soybean and dry bean), and mid-October to early November (corn) each year. Barley was harvested with a plot combine from a $180-\mathrm{m}^{2}\left(215-\mathrm{yd}^{2}\right)$ area of each plot for yield determination. Soybean and dry bean yields were determined by hand harvesting a $4-\mathrm{m}^{2}\left(4.8-\mathrm{yd}^{2}\right)$ area in 2003 and 2005. Corn yields were determined by hand harvesting the corn ears from an $11.6-\mathrm{m}^{2}\left(13.9-\mathrm{yd}^{2}\right)$ area of each plot each year. The corn ears were shelled with a corn sheller to determine grain and cob weights. Crop yields were measured at physiological maturity (Halvorson and Reule 2007; Halvorson et al. 2006). The 2002 barley yields in the 
NTCBS rotation were reduced by a hail storm on July 3, 2002, which reduced grain yield potential about $40 \%$ to $50 \%$. Standard moisture content yield data $(12 \%$ moisture for barley, $15.5 \%$ for corn, $14 \%$ for dry bean, and $13 \%$ for soybean) was used to determine SCI values in RUSLE2. Analysis of variance was performed on grain yields expressed on an oven dry basis by cropping system and $\mathrm{N}$ level. Above-ground corn biomass was determined in mid-Sept. in 2002 and midOct. in other years by hand harvesting 15 whole corn plants from a $1.5-\mathrm{m}^{2}\left(1.8-\mathrm{yd}^{2}\right)$ or larger area from each plot. The corn plants were separated into grain, cobs, and stover for total biomass determination. Above-ground biomass of soybean, dry bean, and barley was determined at physiological maturity from a $2-\mathrm{m}^{2}\left(2.4-\mathrm{yd}^{2}\right)$ area of each plot (Halvorson and Reule 2006, 2007).

Soil Sampling and Analyses. Soil samples were collected from depths of 0 to 5 and 5 to $10 \mathrm{~cm}$ ( 0 to 2 in and 2 to 4 in) to determine $\mathrm{pH}$, wet aggregate stability (WAS), electrical conductivity (EC), P, microbial biomass carbon (MBC), and $\beta$-glucosidase activity (BGA) in May, 2007. Samples for bulk density (BD), SOC, soil inorganic carbon (SIC), and POMC were collected using a $5-\mathrm{cm}$ (2-in) diameter core sampler at 0 - to $7.6-$ and $7.6-$ to $15.2-\mathrm{cm}(0-$ to 3- and 3- to 6-in) depths in October, 2006 (BD, SOC, and SIC) or November, 2005 (POMC). Since the SCI calculates qualitative changes in SOC in the upper $10 \mathrm{~cm}(4$ in) of the soil surface, soil analyses were calculated as depth-weighted averages over the 0 to $10 \mathrm{~cm}$ (0 to $4 \mathrm{in}$ ) depth for comparisons in this study. Bulk density was determined using the soil core method as described by (Blake and Hartge 1986). Soil BD was used to calculate SOC mass on an area basis. Soil samples were pre-screened through a $2-\mathrm{mm}$ $(0.08$-in) sieve to remove large pieces of plant material before further grinding with a flail type soil grinder to pass through a 2 $\mathrm{mm}$ (0.08 in) screen. Sieved samples were used in the POMC analysis according to the method of Gregorich and Ellert (1993). Soil samples collected for total soil carbon, SIC, and SOC were ground to pass a 150 $\mu$ screen (0.006 in) screen using a roller mill and were analyzed for $\mathrm{C}$ content using an Elementar Vario Macro C-N analyzer (Elementar Americas Inc., Mt. Laurel, New Jersey). Soil inorganic C was determined using the method of Sherrod et al. (2002).
Soil organic C was the difference between total soil carbon and SIC.

Samples retained for microbial analyses were transported to the laboratory in iced coolers and kept at $4^{\circ} \mathrm{C}\left(39^{\circ} \mathrm{F}\right)$ until analyzed no later than two weeks after sampling. Microbial biomass C content was determined by the chloroform-fumigationextraction method using $0.5 \mathrm{M} \mathrm{K}_{2} \mathrm{SO}_{4}$ as an extractant (Vance et al. 1987). Each sample was duplicated, and results were expressed on an oven-dry basis. Soil water content was determined by drying the sample at $105^{\circ} \mathrm{C}\left(221^{\circ} \mathrm{F}\right)$ for 48 hours. Enzyme activity (BGA) was assayed using $1 \mathrm{~g}(0.035 \mathrm{oz})$ of air-dried soil as described in Tabatabai (1994). Soil pH and EC were determined on a $1: 1$ soil:solution ratio using $20 \mathrm{~g}(0.7 \mathrm{oz})$ of air-dry soil that had been passed through a $2 \mathrm{~mm}$ (0.08 in) sieve. The EC was measured with an YSI Model 30 conductivity meter and $\mathrm{pH}$ was measured using a Thermo Orion Model $420 \mathrm{pH}$ meter. Wet aggregate stability was measured according to the procedure of Cambardella and Elliott (1993) and expressed as the percentage of total soil with water-stable aggregates $>250 \mu \mathrm{m}(0.01$ in) in diameter. Soil $\mathrm{P}$ was determined using the Olsen $\left(\mathrm{NaHCO}_{3}\right)$ procedure (Frank et al. 1998).

Soil Conditioning Index and Soil Management Assessment Framework Determination. Details describing the SCI and the SCI sub-factors are found in the USDA NRCS National Agronomy Manual, Part 508 (USDA NRCS 2002). In this study, the SCI values and sub-factors for OM, field operations, and erosion were determined using RUSLE2, version 1.25.8 (Dec. 2005) Wind erosion estimates are also needed to determine SCI for fields where wind erosion is active, but it is not estimated in RUSLE2 and was estimated using an MS Excel spreadsheet program (Sporcic et al. 1998) based on the Wind Erosion Equation (Woodruff and Siddoway 1965) using the management period method. Specific management practices and crop yields for each $\mathrm{N}$ rate, year, and replication were entered into the programs to calculate SCI and the SCI sub-factors.

Eight soil properties were selected and used as indicators of SQ using SMAF: MBC, TOC, BGA, pH, P, EC, WAS, and BD. The SMAF scored values were determined using scoring curves that were related with the observed soil properties using an MS Excel spreadsheet based on the method described by Andrews et al. (2004). The scoring curves take the general forms of less is better (e.g., $\mathrm{BD})$, more is better (e.g., organic C), and optimal values (e.g., $\mathrm{pH}$ ) (Wienhold et al. 2006). The scoring curves used in this study included physical (WAS using macro-aggregate percentage and $\mathrm{BD})$, chemical $(\mathrm{pH}$, $\mathrm{EC}, \mathrm{P}$, and TOC), and biological (MBC and BGA) soil properties. The SMAF soil property index values, called scored values, were combined and integrated into a single SQI that varied between 0 and 1 , with 0 indicating no SQ value and 1 indicating the highest value.

Statistical analyses were performed using procedures of SAS version 9.1 (SAS Institute 2002). Analyses of variance (ANOVA) were performed with Proc Mixed using a randomized complete block, with three replications (four replications for the CTCC), testing three $\mathrm{N}$ rates within each of five cropping systems. All statistical differences were evaluated at the $p=0.05$ level.

\section{Results and Discussion}

This study evaluated the use of two indexes of SQ for agricultural use, the SCI and SMAF, and was conducted after the cropping systems had been in the field for six years. The SCI calculates qualitative changes in SOC based on organic material returned to the soil, field operations, and wind and water erosion (USDA NRCS 2002) and estimates the future trends in SOC levels. However, the SMAF combines physical, chemical, and biological indicators for an overall assessment of current soil quality (Andrews et al. 2002, 2004; Karlen et al. 2006). Although the SCI was intended to estimate only SOC, SOC is related to other soil properties that affect soil function and ecosystems services. Organic matter acts as a binding agent for soil particles, helps to hold nutrients and water in soil, and provides the energy, substrates and biological diversity to support biological activity, which affects soil aggregation and water infiltration (Franzluebbers 2002). In this study, we evaluated these indexes by comparing soil physical (WAS and BD), chemical (SOC, POMC, EC, P, and $\mathrm{pH}$ ), and microbiological (MBC and $\mathrm{BGA}$ ) properties with index values for five cropping systems (rotations) at three $\mathrm{N}$ levels. Analyses of variance for each soil property and index by rotation showed significant rotation differences for all tests (table 1). The scored values are signified by the letter $\mathrm{S}$ following 
Table 1

Nitrogen level and rotation effects on soil properties, crop yields, and soil quality indexes.

\begin{tabular}{|c|c|c|c|c|c|c|c|c|c|c|c|}
\hline \multirow[b]{2}{*}{ Source } & \multicolumn{3}{|c|}{ Effects test $p>F$} & \multicolumn{3}{|c|}{$\underline{\text { Nitrogen level } †}$} & \multicolumn{5}{|l|}{ Rotation $\ddagger$} \\
\hline & Rotation (R) & $\mathrm{N}$-Level (N) & $R * N$ & 1 & 2 & 3 & NTCC & NTCB & NTCS/D & NTCSB & стсс \\
\hline \multicolumn{12}{|l|}{ Soil properties } \\
\hline $\begin{array}{l}\text { Microbial biomass carbon } \\
\text { ( } \mathrm{mg} \mathrm{C} \mathrm{kg-1} \text { soil) }\end{array}$ & 0.0001 & 0.2683 & 0.4830 & $264.53 a \S$ & $278.31 a$ & $291.29 a$ & 299.35ab & $314.70 a$ & $315.64 a$ & $243.16 \mathrm{bc}$ & $217.35 c$ \\
\hline Total soil organic carbon (\%) & 0.0068 & 0.0193 & 0.8042 & $1.17 \mathrm{~b}$ & $1.25 a b$ & $1.28 \mathrm{a}$ & $1.33 a$ & $1.22 \mathrm{ab}$ & $1.22 a b$ & $1.24 a b$ & $1.15 b$ \\
\hline $\begin{array}{l}\beta \text {-glucosidase activity } \\
\quad\left(\mathrm{mg} \mathrm{PN} \mathrm{kg-1} \text { soil h}^{-1}\right)\end{array}$ & 0.0001 & 0.0001 & 0.0254 & $126.25 b$ & $141.95 b$ & $165.72 a$ & $173.51 a$ & $165.72 a$ & 151.06ab & $129.91 b$ & $103.00 \mathrm{c}$ \\
\hline $\mathrm{pH}$ & 0.0001 & 0.0012 & 0.0229 & $7.93 a$ & $7.92 a$ & $7.82 b$ & $7.79 b$ & $7.79 b$ & $8.01 a$ & $7.95 a$ & $7.90 \mathrm{a}$ \\
\hline Wet aggregate stability (\%) & 0.0001 & 0.7859 & 0.9672 & $60.11 a$ & $60.05 a$ & $57.54 a$ & $76.89 a$ & $70.98 a b$ & $58.36 \mathrm{bc}$ & $47.99 \mathrm{~cd}$ & $41.94 d$ \\
\hline Phosphorus (mg kg-1) & 0.0001 & 0.5293 & 0.1000 & $24.78 a$ & $26.15 a$ & $24.02 a$ & $32.50 a$ & $24.50 \mathrm{~b}$ & $24.28 b$ & $27.06 a b$ & $16.58 \mathrm{c}$ \\
\hline Bulk density $\left(\mathrm{Mg} \mathrm{m}^{-3}\right)$ & 0.0001 & 0.5951 & 0.6165 & $1.45 a$ & $1.43 a$ & $1.43 a$ & $1.46 a b$ & $1.53 a$ & $1.45 a b$ & $1.44 b$ & $1.32 \mathrm{c}$ \\
\hline $\begin{array}{l}\text { Particulate organic matter } \\
\quad \text { carbon (\%) }\end{array}$ & 0.0054 & 0.1532 & 0.7197 & $0.36 a$ & $0.37 a$ & $0.41 a$ & $0.46 a$ & $0.40 \mathrm{ab}$ & $0.36 b$ & $0.35 b$ & $0.34 b$ \\
\hline Electrical conductivity $\left(\mu \mathrm{S} \mathrm{cm}{ }^{-1}\right)$ & 0.0001 & 0.0003 & 0.0004 & $513.52 b$ & $508.98 b$ & $595.55 a$ & $474.22 \mathrm{bc}$ & $541.67 \mathrm{~b}$ & $427.06 c$ & $446.78 \mathrm{c}$ & $807.04 a$ \\
\hline \multicolumn{12}{|l|}{ Crop properties } \\
\hline Yield $\left(\mathrm{Mg} \mathrm{ha}^{-1}\right)$ & 0.0001 & 0.0001 & 0.1298 & $4.82 \mathrm{c}$ & $6.52 b$ & $8.01 \mathrm{a}$ & $6.70 \mathrm{ab}$ & $6.05 b$ & $6.09 b$ & $5.45 b$ & $7.96 \mathrm{a}$ \\
\hline Residue Dry Mass (Mg ha-1 $\left.{ }^{-1}\right)$ & 0.0001 & 0.0001 & 0.5175 & $5.04 \mathrm{c}$ & $6.21 b$ & $7.36 a$ & $6.96 a$ & $6.08 a b$ & $6.00 \mathrm{ab}$ & $5.08 b$ & $6.90 a$ \\
\hline \multicolumn{12}{|c|}{ Soil quality indicator scores and indexes } \\
\hline Microbial biomass carbon score & 0.0004 & 0.6084 & 0.7860 & $0.81 a$ & $0.82 a$ & $0.86 a$ & $0.87 a$ & $0.93 a$ & $0.93 a$ & $0.75 a b$ & $0.68 b$ \\
\hline Total soil organic carbon score & 0.0056 & 0.0213 & 0.7546 & $0.18 b$ & $0.21 \mathrm{ab}$ & $0.22 a$ & $0.24 a$ & $0.20 \mathrm{ab}$ & $0.20 \mathrm{ab}$ & $0.20 a b$ & $0.18 b$ \\
\hline$\beta$-glucosidase activity score & 0.0001 & 0.0001 & 0.0500 & $0.39 c$ & $0.48 b$ & $0.61 a$ & $0.64 a$ & $0.61 a$ & $0.54 a b$ & $0.40 \mathrm{~b}$ & $0.25 c$ \\
\hline pH Score & 0.0001 & 0.8549 & 0.0001 & $0.72 b$ & $0.72 b$ & $0.75 a$ & $0.76 \mathrm{a}$ & $0.76 \mathrm{a}$ & $0.69 c$ & $0.71 b c$ & $0.73 b$ \\
\hline Wet aggregate stability score & 0.0033 & 0.6526 & 0.9216 & $0.96 a$ & $0.96 a$ & $0.94 a$ & $1.00 \mathrm{a}$ & $1.00 \mathrm{a}$ & $0.96 a b$ & $0.91 a b$ & $0.88 b$ \\
\hline Phosphorus score & 0.0001 & 0.5025 & 0.2344 & $0.99 a$ & $0.99 a$ & $0.99 a$ & $1.00 a$ & $0.99 a$ & $0.99 a$ & $1.00 \mathrm{a}$ & $0.97 \mathrm{~b}$ \\
\hline Bulk density score & 0.0001 & 0.5898 & 0.3028 & $0.37 a$ & $0.40 a$ & $0.37 a$ & $0.34 b$ & $0.29 b$ & $0.36 b$ & $0.36 b$ & $0.54 a$ \\
\hline Soil quality index & 0.0001 & 0.0218 & 0.5209 & $0.68 b$ & $0.70 a b$ & $0.72 a$ & $0.74 a$ & $0.72 \mathrm{a}$ & $0.71 a b$ & $0.67 b c$ & $0.65 c$ \\
\hline Organic matter SCl* & 0.0001 & 0.0001 & 0.0003 & $0.88 c$ & $1.49 b$ & $1.94 a$ & $1.24 \mathrm{bc}$ & $1.74 a$ & $1.10 \mathrm{c}$ & $1.69 a$ & $1.42 b$ \\
\hline Soil conditioning index & 0.0001 & 0.0001 & 0.0001 & $0.75 c$ & $1.00 \mathrm{~b}$ & $1.19 a$ & $1.08 b$ & $1.26 \mathrm{a}$ & $1.03 b$ & $1.26 \mathrm{a}$ & $0.27 c$ \\
\hline
\end{tabular}

* Organic matter subfactor of the Soil Conditioning Index.

† 1 = 0 nitrogen; 2 = $67 \mathrm{~kg} \mathrm{~N} \mathrm{ha}^{-1}$ for corn, $45 \mathrm{~kg} \mathrm{~N} \mathrm{ha}^{-1}$ for barley, and $22 \mathrm{~kg} \mathrm{~N} \mathrm{ha}^{-1}$ for soybean and dry bean; $3=202,224$, or $246 \mathrm{~kg} \mathrm{~N}^{-1}$ for corn and $56 \mathrm{~kg} \mathrm{~N} \mathrm{ha}^{-1}$ for soybean and dry bean, and $112 \mathrm{~kg} \mathrm{~N} \mathrm{ha}^{-1}$ for barley.

‡ NTCC = no-till continual corn rotation; NTCB = no-till corn-barley rotation; NTCS/D = no-till corn-soybean/dry bean rotation; NTCSB= no-till corn-soybean-barley rotation; CTCC $=$ coventional till continual corn study.

$\S$ Means followed by the same letter within the same row and within nitrogen levels or rotations are not significantly different at $p=0.05$.

the soil property term as listed above in this manuscript. For example, the scored indicator value for bulk density is BDS.

Effect of Nitrogen Level on Soil Properties, Scored Values, and Soil Quality Indexes. Differences due to $\mathrm{N}$ level were found for the crop grain yields and residues, for total SOC, BGA, EC, $\mathrm{pH}$ and the total SOCS, BGAS, OM SCI sub-factor, and SQI and SCI values (table 1). Although there were no differences among $\mathrm{N}$ levels for $\mathrm{pHS}$, there was a significant rotation by $\mathrm{N}$ level interaction. The EC values were not tested because the low level of EC found in these plots resulted in all plots having an ECS $=1$.
Among soil properties that showed differences due to $\mathrm{N}$ level, increases in $\mathrm{N}$ level generally resulted in an increase in the soil property tested (table 1). The SOC and BGA were lowest at the N1 level and were significantly lower than the N3 level, where they were the highest. Results at the N1 and N2 levels were statistically the same.

With the exception of EC, each of the soil properties that showed differences due to $\mathrm{N}$ level also had differences due to $\mathrm{N}$ level for their respective scored value. However, the scored values for individual soil indicator properties varied in how the differences among $\mathrm{N}$ levels were expressed. For exam- ple, the SOCS increased in the same relative direction and indicated the same significance levels as the measured soil SOC value. In contrast, although the BGAS increased in the same manner as the soil BGA value, the BGAS showed significant differences among all $\mathrm{N}$ levels, while the soil BGA found no statistical difference among the N1 and N2 levels. Finally, the pHS had the same significance levels as the soil $\mathrm{pH}$, but the $\mathrm{pHS}$ increased with $\mathrm{N}$ level while the soil $\mathrm{pH}$ decreased with $\mathrm{N}$ level (table 1).

All of these general patterns were observed and described by Andrews et al. (2004) where they discussed four general patterns in treat- 
ment differences when treatment means for the scored values are compared with measured soil properties using ANOVAs. Our SOCS and BGAS patterns followed their pattern 1, where the measurements tend to fall on the ascending portion of the scoring curve. They found similar results for SOC for a National Resources Inventory study and at a California site. Our pHS pattern for differences among $\mathrm{N}$ levels follows Andrews et al. (2004) pattern 2 where the observed and scored values had opposite results. They also observed this pattern for $\mathrm{pH}$ at a California test site. This occurred in our study because the $\mathrm{pH}$ values all occurred in the descending portion of the scoring curves where the SQI decreased as $\mathrm{pH}$ increased.

Although the SCI made unambiguous, non-overlapping distinctions among $\mathrm{N}$ levels, some overlapping occurred among $\mathrm{N}$ levels with SQI (table 1). The SQI increased with $\mathrm{N}$ level, with N1 not significantly different from $\mathrm{N} 2$, and the N2 level not significantly different from N3 level, while N3 level was significantly greater than N1 level (table 1). The SCI also increased with $\mathrm{N}$ level. However, each successive increase in $\mathrm{N}$ level produced a significant increase in SCI value. This trend in SCI seems to follow the increase in crop yield and residue (oven dry values) with $\mathrm{N}$ level. Direct comparison of the SCI and SQI by $\mathrm{N}$ level shows a large separation between SCI values for each $\mathrm{N}$ level and a much more subtle separation among $\mathrm{N}$ levels for the SQI (figure 1).

Effect of Cropping Systems on the Soil Management Assessment Framework Soil Quality Index. The soil property values and their SQ scored values are listed by rotation in table 1 , and a side-by-side comparison of each soil property with its scored value is shown in figure 2. It is important to consider the crop, tillage, and residue returned to the soil when considering differences among cropping systems. Each graph in figure 2 has the NT systems on the left side of the horizontal axis and the CT on the far right. Among the NT systems, there is a tendency for lower residue amounts as other crops are introduced into the system (going left to right in graph in figure 2). There were statistical differences in crop residue among cropping systems with NTCB, NTCS/D, and NTCSB having the lowest residue returned to the soil (table 1). The two continual corn systems (NTCC and CTCC) had the same

\section{Figure 1}

Effect of nitrogen level on the soil quality index and soil conditioning index. Error bars indicate standard errors.

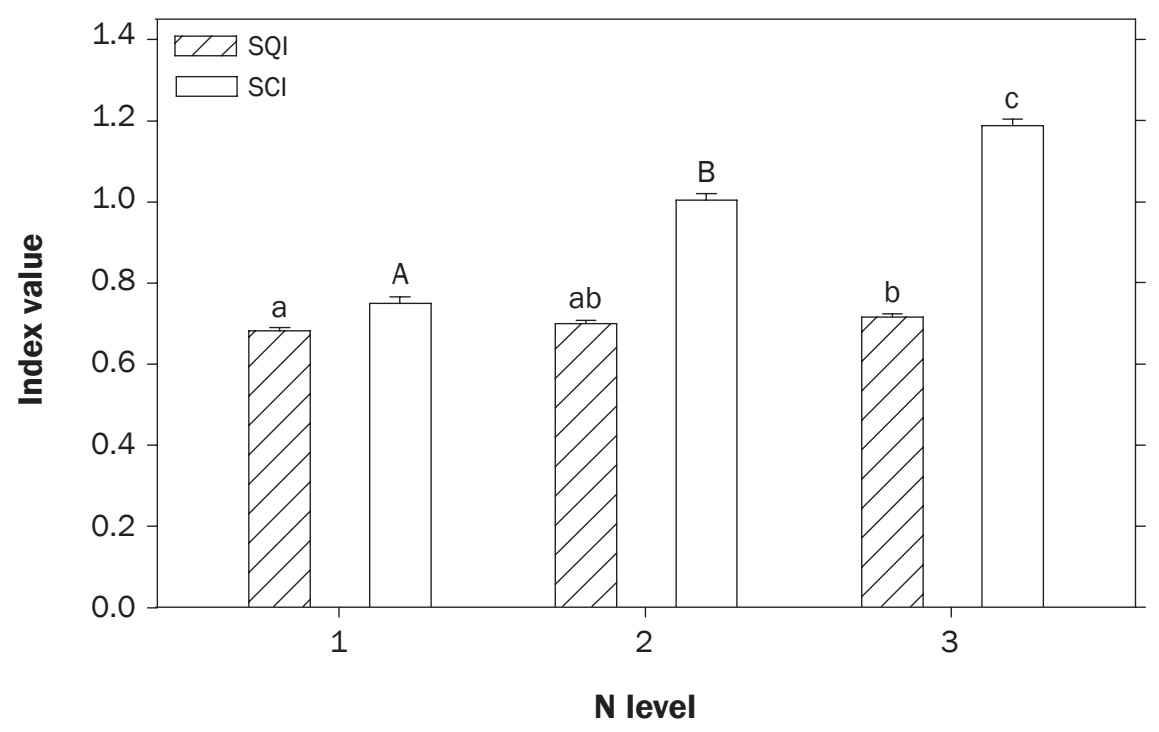

Note: Bars with the same letter and case are not significantly different at $p=0.05$.

but greater amounts of residue returned than the other systems.

Study of the general patterns and trend of the side-by-side comparisons reveals three distinct patterns. The first pattern is the most straightforward, with the indicators and scored values having the same general trend and identical statistical differences. We see this pattern for SOC (figure $2 b$ ) and BGA (figure 2c). Total SOC and BGA and their scored values tend to decrease with tillage and as other crops are introduced into the NTCC system, and they identify the same statistical differences among cropping systems. This pattern corresponds to the first pattern described by Andrews et al. (2004). Enzyme activities have been correlated with SOC in the past (Tabatabai 1994.)

In the second and most common pattern, the soil properties and the scored values have the same general trend, but more differences among management systems were found for the soil property values. Identifying significant differences in the soil property values despite seeing few or none in the scored values is important because it indicates the observed values are occurring on an asymptote or plateau in the scoring curves. This pattern is found for $\mathrm{MBC}$, WAS, and $\mathrm{P}$ (figure 2a, 2e, and $2 \mathrm{f}$, respectively). This pattern is similar to, but not the same as, the third pattern of Andrews et al. (2004). In our pattern, both the soil property and scored
SQ value showed differences among cropping systems, but the soil properties showed more differences than the scored SQ values. For example, the measured MBC value separated the systems into three overlapping groups, while the MBCS identified only two slightly overlapping groups. A similar pattern was found for $\mathrm{P}$, and even greater statistical differences among cropping systems were found for WAS. In this case, the WASS had two overlapping groups while the measured WAS value had four overlapping groups. This degree of statistical resolution of the WAS compared to the scored value is expected considering that although the range of measured WAS values was great and statistical differences were easily discerned, the scored values were all near the top of the scoring curve with little variation.

In the third and final pattern observed, describing the relationships of the soil property and scored SQ value, the soil properties and scored values showed opposite trends. As $\mathrm{pH}$ and $\mathrm{BD}$ values increased, the scored pHS and BDS values decreased (figure $2 \mathrm{~d}$ and $2 \mathrm{~g}$, respectively). This general pattern corresponds to pattern 2 of Andrews et al. (2004). However, in our study these values had opposite trends for different reasons. As discussed earlier, the measured $\mathrm{pH}$ values had opposite trends because all of the scored $\mathrm{pH}$ values were on the descending portion of a bell-shaped optimum value-type scoring 
Figure 2

Comparison of soil property values with soil property scored values for (a) microbial biomass carbon (MBC), (b) soil organic carbon (SOC), (c) B-glucosidase activity, (d) pH, (e) wet aggregate stability (WAS), (f) soil phosphorus (P), and (g) bulk density.
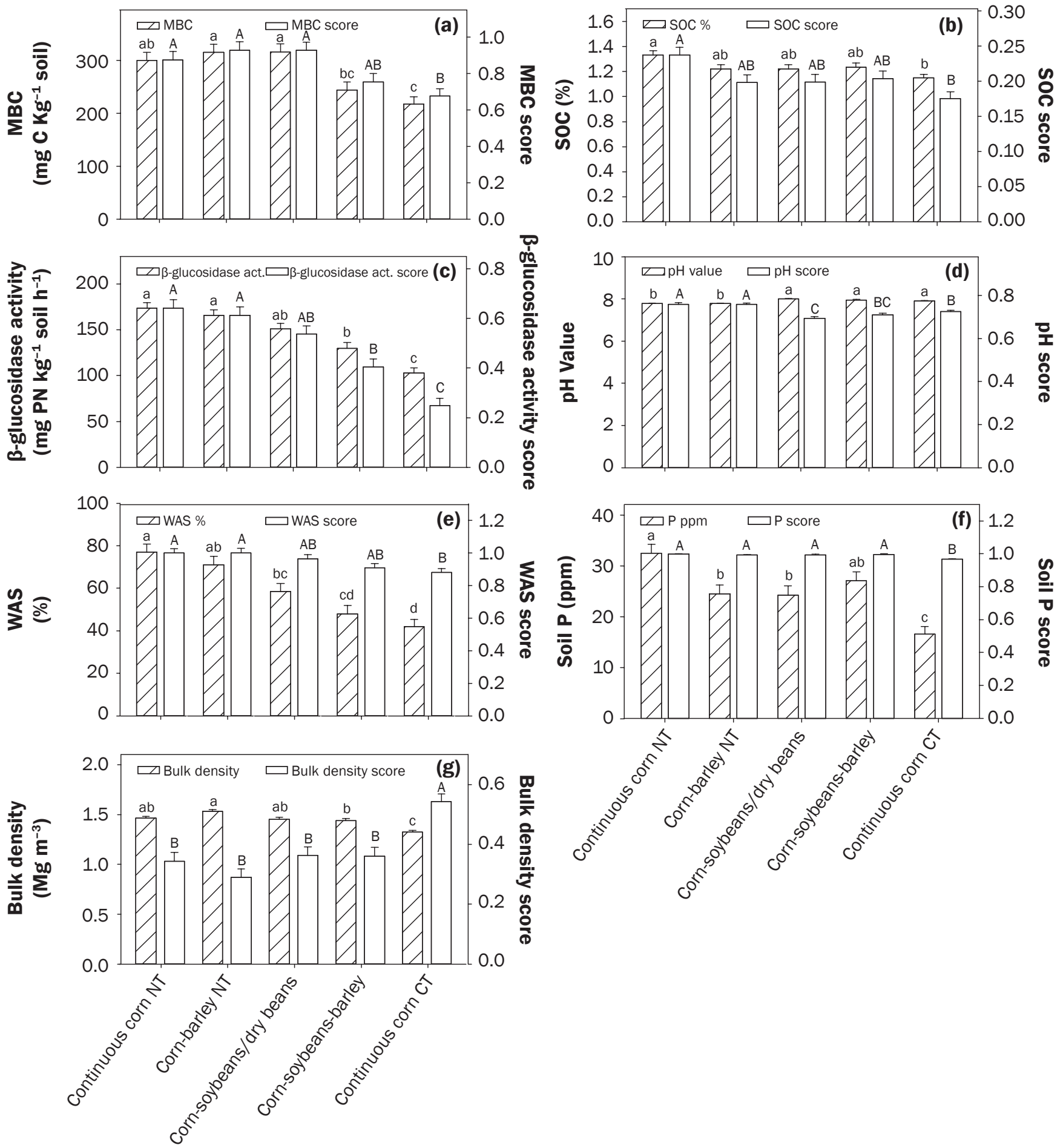

Notes: Error bars indicate standard errors. Bars with the same letter and case are not significantly different at $p=0.05$. 
Figure 3

Comparison of soil property values with soil quality index (SQI) and soil conditioning index (SCI) values for (a) microbial biomass carbon (MBC), (b) soil organic carbon (SOC), (c) B-glucosidase activity, (d) pH, (e) wet aggregate stability (WAS), (f) phosphorus, (g) bulk density, and (h) particulate organic matter carbon (POMC).
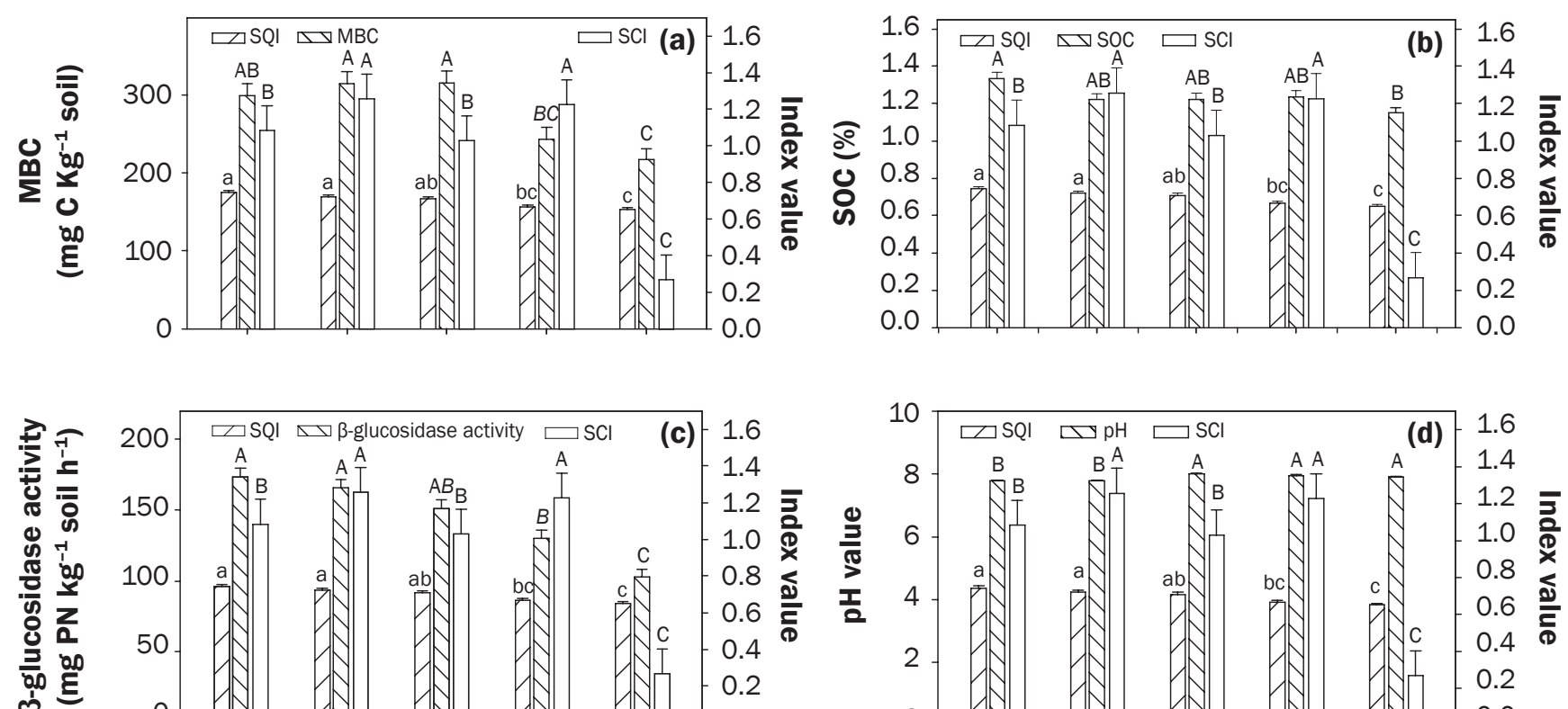

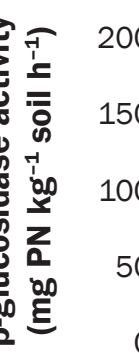
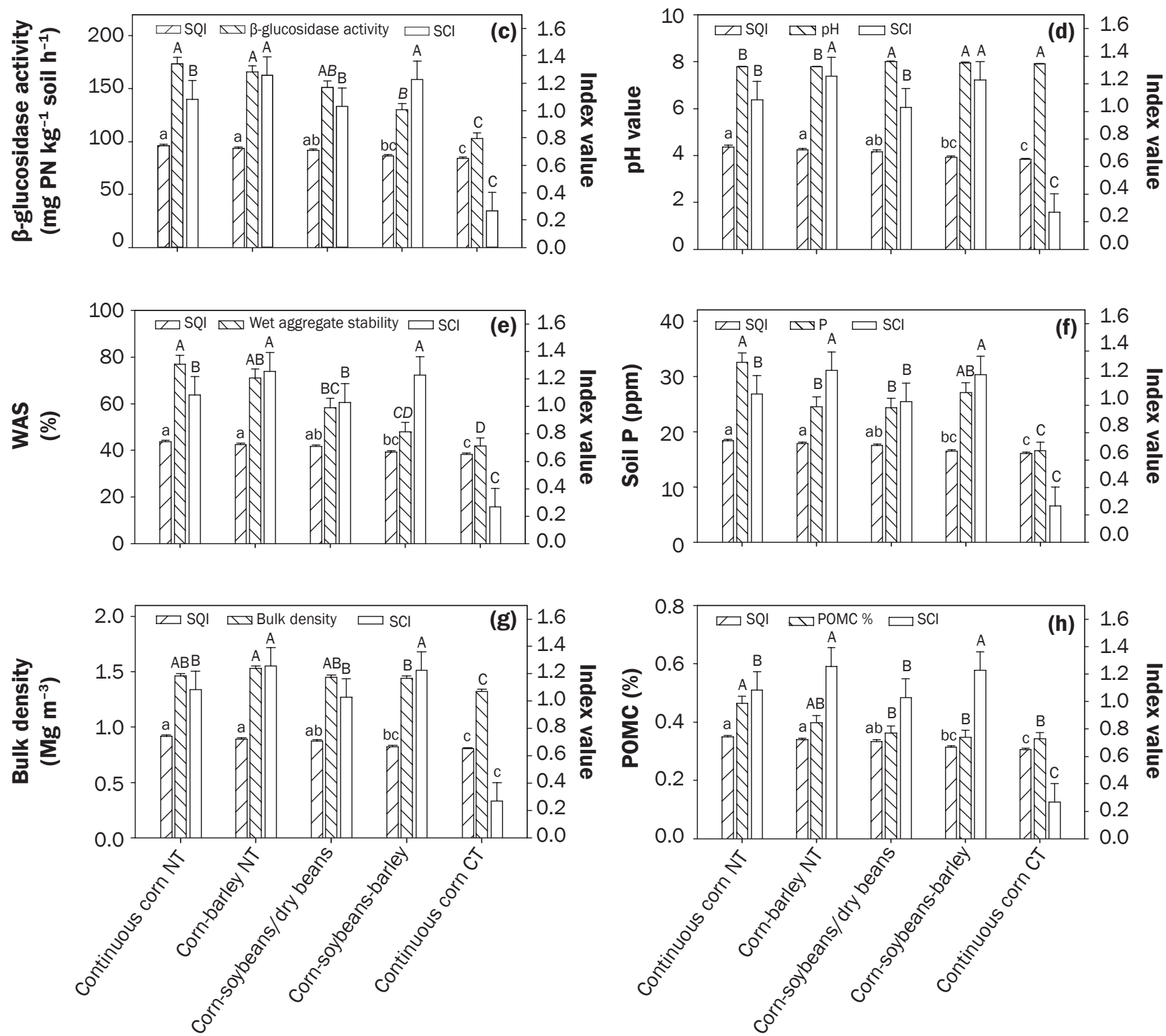

Note: Error bars indicate standard errors. Bars with the same letter and case are not significantly different at $p=0.05$. 
Table 2

Cropping system yields, erosion estimates, and soil conditioning index sub-factors by nitrogen level.

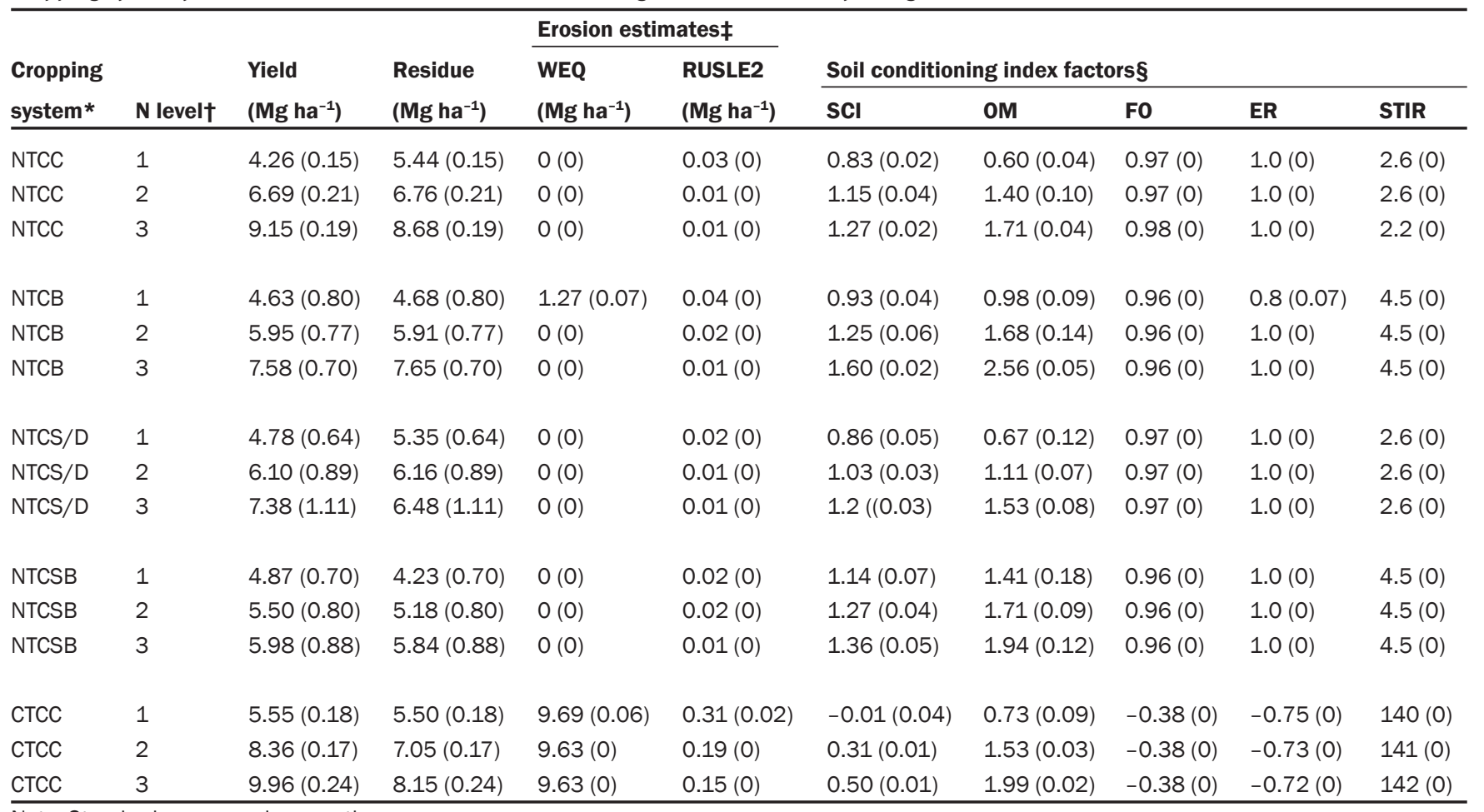

Note: Standard errors are in parentheses.

* NTCC = No-till continual corn rotation; NTCB = No-till corn-barley rotation; NTCS/D = No-till corn-soybean/dry bean rotation; NTCSB= no-till corn-soybean-barley rotation; CTCC $=$ coventional till continual corn study.

† 1 = 0 nitrogen; 2 = $67 \mathrm{~kg} \mathrm{~N} \mathrm{ha}^{-1}$ for corn, $45 \mathrm{~kg} \mathrm{~N} \mathrm{ha}^{-1}$ for barley, and $22 \mathrm{~kg} \mathrm{~N} \mathrm{ha}^{-1}$ for soybean and dry bean; $3=202,224$, or $246 \mathrm{~kg} \mathrm{~N}^{-1}$ for corn and $56 \mathrm{~kg} \mathrm{~N} \mathrm{ha}^{-1}$ for soybean and dry bean, and $112 \mathrm{~kg} \mathrm{~N} \mathrm{ha}^{-1}$ for barley.

$\ddagger$ WEQ = wind erosion equation; RUSLE2 = revised universal soil loss equation.

$\S \mathrm{SCl}=$ soil conditioning index value; $\mathrm{OM}=\mathrm{SCl}$ organic matter sub-factor; $\mathrm{FO}=\mathrm{SCl}$ field operations subfactor; $\mathrm{ER}=\mathrm{SCl}$ erosion subfactor; $\mathrm{STIR}=\mathrm{SCl}$ soil tillage intensity rating.

curve. The BD comparison of measured and scored values had opposite trends because the BD scoring curves represent the 'less-is-better' effect and SQ increased with decreasing BD. In addition, although these patterns are similar in their general trend, they differed in the statistical resolution of the parameter. For example, there were more statistical differences identified with the pHS values than the measured $\mathrm{pH}$ values. Conversely, there were more statistical differences identified by the $\mathrm{BD}$ values than by the BDS values.

A comparison of scored values among cropping systems shows that the CTCC had significantly lower scored values than NTCC, with the exception of BDS (table 1). The NT systems had a higher observed BD that produced a lower BDS than the CT system. The significant differences among cropping systems varied with the scored values tested. For example, the CTCC had the same scored value as the NTCSB for the MBCS and the pHS (figures $2 \mathrm{a}$ and $2 \mathrm{~d}$, respectively); the CTCC had the same scored value as the NTCS/D and NTCSB for the WASS and the PS (figures $2 \mathrm{e}$ and $2 \mathrm{f}$, respectively); and the CTCC had the same scored value as the NTCB, NTCS/D and NTCSB for the SOCS (figure 2b). So using an SQI approach on individual soil properties may lead to different outcomes depending upon the scored value selected for comparison. For this reason, an important step in the determining an index of SQ using SMAF is to combine the individual indicator scores into a single value that describes the overall condition of the soil, without the distraction of (potentially) conflicting individual soil property indicator scores (Andrews et al. 2004).

The comparison of the integrated SQI values is shown in figure 3. The SQI separated the cropping systems into several groups with decreasing SQI with increasing tillage and decreasing residue as lower residue crops are introduced to the cropping system. The NTCSB and CTCC systems had the lowest
SQI. The highest SQI was measured in the NTCC, NTCB, and NTCS/D systems. The NTCS/D and NTCSB systems had the same SQI (statistically) but overlapping SQI values for the NTCC, NTCB, and NTCSB systems.

Effect of Cropping Systems on the Soil Conditioning Index. The SCI is determined on the basis of crop and tillage management, organic matter returned to the soil, and estimated erosion. The sub-factors representing the effect of OM, FO, and ER are shown in table 2. Very little variation among replications was found for the SCI sub-factors so only means are presented. Statistical analyses revealed differences among cropping systems for SCI and the OM sub-factor (table 1). In all cropping systems, the OM sub-factor (representing organic material returned to the soil) increased with increasing $\mathrm{N}$ level. This result was due to the increased grain yield (table 1).

The STIR is the soil tillage intensity rating estimated in RUSLE2 and is based on 
the frequency and type of operations used to produce the crop (USDA NRCS 2007b). The rating increases with increasing soil disturbance. Although the STIR values are very similar, the NTCC and NTCS/D systems have a slightly lower STIR values than the NTCB and NTCSB systems that include barley in the cropping systems due to slight differences in the planter specified in the model. The CTCC system has a far greater STIR value (>30 to 50 times greater) than the other systems and produced the only negative FO values. Aggressive tillage exposes the soil and increases its vulnerability to wind erosion. Since the plots were level, estimates of water erosion were minimal. The high wind erosion estimates resulted in negative ER sub-factor values for the CTCC system plots (table 2 ).

Direct comparisons of the SCI with soil properties, as done above for SQI, was not possible because the SCI is not based on observed soil properties but rather on model output using soil, climate, crop management, and grain yield data. However, a graphical comparison of the SCI values with the soil properties used to determine the SQI can show how SCI relates to important soil property indicators not directly used to develop the index (figure 3).

The SCI values separated the cropping systems into three groups with no overlap among them (figure 3). The NTCB and NTCSB had the highest SCI; the NTCC and NTCS/D had a significantly lower SCI; and the CTCC had the lowest SCI. None of the ANOVAs for the soil properties tested separated the cropping systems into three groups with no overlap. Although most of the soil properties identified at least three different groups, most of the analyses indicated overlap among cropping systems.

Although the SCI was developed to indicate qualitative changes in SOC, the SOCS was more successful in separating the cropping systems based on SOC content. The SOCS in figure $2 \mathrm{~b}$ made the same separations of cropping systems as the measured SOC content value. However, the SCI failed to associate the NTCB, NTCS/D, and NTCSB systems with the CTCC as suggested by the SOC content value (figure $3 \mathrm{~b}$ ). The RUSLE2 simulations of SCI showed that NTCC had a significantly greater SCI than CTCC.

These results also show SQI and SCI differed in their ability to detect differences among crop management systems. Although both SQI and SCI separated the NTCC and CTCC, the SQI identified a significant difference between NTCB and NTCSB not recognized by SCI (figure 3). Thus, we accept the hypothesis that the SQI produced by SMAF can detect smaller differences among crop management systems than SCI.

The results of this study seem to conflict with a recent study of semiarid soils in west Texas (Zobeck et al. 2007). In the west Texas study, SCI was more closely associated with POMC than with total SOC. However in this study of soil in northern Colorado, the SCI was more closely correlated with SOC $(r=0.52, p<0.0001)$ than POMC $(r=0.27$, $p=0.106)$ (data not shown). In addition, the SOCS was very highly correlated with SOC $(r=0.99)$ and not well-correlated with POMC $(r=0.28, p=0.057)$. The high correlation of the SOCS with SOC is expected because SOCS was developed using scoring curves developed from SOC data sets tailored to specific soils and climate data sets. Comparison of the SQI and SCI with POMC is shown in figure $3 \mathrm{~h}$. Zobeck et al (2007) also found considerable variation in SCI estimates in cropping systems that were classified as the same system by soil conservationists and so suggested a buffer of plus or minus 0.2 for SCI determinations. A consideration of this buffer would suggest that according to the calculated SCI values, all cropping systems in this northern Colorado study would have positive SCI values and meet the SCI qualification for government programs requiring a positive SCI value.

\section{Summary and Conclusions}

The SCI and SMAF provide an evaluation of the soil for agricultural use and management. However, they have different data requirements and differ in the resolution they provide in differentiating among competing management systems. The SCI was designed to estimate the consequences of crop management on SOC and uses information on soils, climate, and crop management as required by RUSLE2 and the Wind Erosion Equation. Field sampling of the soil is not required. Considerable training in the use of the models is required to ensure proper results. The SQI estimated through SMAF uses a set of soil measurements to determine the current SQ based on scoring curves of properties indicative of soil functions considered important for agricul- tural use and management. The SMAF SQI requires information about the soil, climate, and crop type, but detailed information about crop management is not required. However, laboratory analyses of field soil samples are required. The data input is straightforward, and it is now possible to input the data via the Internet (USDA NRCS 2007a).

Both indexes seemed to differentiate among three levels of $\mathrm{N}$ in this study. The SQI clearly distinguished the plots with a very high level of $\mathrm{N}$ from plots with no $\mathrm{N}$. However, the mid-level of $\mathrm{N}$ was statistically the same as both extreme levels. The SCI values identified clear differences among all $\mathrm{N}$ levels. These differences were the same as those found for the differences among $\mathrm{N}$ levels for crop yields and residue returned to the soil. However, the SQI seemed to make more detailed differentiation among crop management systems compared with SCI. The SCI separated the cropping systems into three groups with no overlap among groups. The NTCB and NTCSB had the highest SCI; the NTCC and NTCS/D had a significantly lower SCI; and the CTCC had the lowest SCI. This result seemed controlled by the emphasis of tillage intensity and estimated erosion used in this index. The SQI also separated the cropping systems into three groups with decreasing SQI with increasing tillage and decreasing residue as lower residue crops are introduced into the cropping system. The cropping systems that included tillage (CTCC) and the low residue crops (NTCSB) had the lowest SQI. The SQI allowed overlap among cropping groups not recognized by SCI.

Since SCI was primarily developed to calculate the consequences of management on SOC, perhaps a more precise test would be to compare the SCI with the SQI based only on the SOC indicator. In a comparison of the SCI and the SOCS, the SOCS was more successful in separating the cropping systems based on SOC. The SOCS made the same statistical differentiations among cropping systems as the SOC soil property values, separating the systems into broad but overlapping groups.

Selection of the most appropriate SQ index seems to be a tradeoff in data requirements, resolution desired, and expected use of the index value. Although previous research has shown that the SCI does separate relatively small differences in management in some cropping systems, in this study the 
SQI provided more resolution to distinguish among management options but requires field sampling and laboratory analysis. The SCI requires only soil management and site data but also requires expert knowledge of the models to ensure the correct result.

Care must be taken when interpreting the output of either SQ model tested. It is very important to understand the history of the site when using a tool like SMAF to make an appropriate interpretation of the results. The SMAF SQI is developed from measured soil properties that may or may not be related to current soil management. The cropping systems used in this study were in the field for six years, and we assume the results represented a steady state condition. However, if the soil management has recently changed, the measured results may represent the former management system and not the current management. Conversely, the SCI estimates the effects of the current management on future SQ and does not necessarily reflect current soil conditions. In this study, the SCI was correlated with SOC, but it did not match the pattern of differences among cropping systems as well as the SQI.

\section{Acknowledgements}

The authors are indebted to Dean Holder, Curtis Reule, Patti Norris, and Bradley Floyd (USDA ARS) for technical assistance with field work and laboratory analysis; and Monty Dollar (retired USDA NRCS agronomist) for technical assistance with SCI calculations. This publication is based upon work supported by the USDA Agricultural Research Service under the USDA ARS GRACEnet Project. The authors are grateful for the helpful comments suggested by anonymous reviewers.

\section{Disclaimer}

Mention of trade names or commercial products is solely for the purpose of providing specific information and does not imply recommendation or endorsement by the USDA ARS.

\section{References}

Andrews, S.S., D.L. Karlen, and C.A. Cambardella. 2004. The soil management assessment framework: A quantitative soil quality evaluation method. Soil Science Society of America Journal 68(6):1945-1962.

Andrews, S.S., D.L. Karlen, and J.P. Mitchell. 2002. A comparison of soil quality indexing methods for vegetable production systems in Northern California. Agriculture, Ecosystems, and the Environment 90(1):25-45.

Cambardella, C.A., and E.T. Elliott. 1993. Carbon and nitrogen distribution in aggregates from cultivated and native grassland soils. Soil Science Society of America Journal 57(4):1071-1076.

Blake, G.R., and K.H. Hartge. 1986. Bulk density. In Methods of Soil Analysis. Part 1. ed. E. Klute, 363-382. Agronomy Monograph No. 9. Madison, WI: American Society of Agronomy and Soil Science Society of America.
Frank, K., D. Beegle, and J. Denning. 1998. Phosphorus. In Recommended Chemical Soil Test Procedures for the North Central Region, ed. J.R. Brown. North Central Publications No. 221 (Revised). Columbia, MO: University of Missouri Agricultural Experiment Station.

Franzluebbers, A.J. 2002. Water infiltration and soil structure related to organic matter and its stratification with depth. Soil and Tillage Research 66(2):197-205.

Gregorich, E.G., and B.H. Ellert. 1993. Light fraction and macroorganic matter in mineral soils. In Soil Sampling and Methods of Analysis, ed. M.R. Carter, 397-407. Boca Raton, FL: Lewis Publishers.

Halvorson, A.D., and C.A. Reule. 2006. Irrigated corn and soybean response to nitrogen under no-till in northern Colorado. Agronomy Journal 98(5):1367-1374.

Halvorson, A.D., and C.A. Reule. 2007. Irrigated corn and barley response to nitrogen under no-till in northern Colorado. Agronomy Journal 99(6):1521-1529.

Halvorson, A.D., A.R. Mosier, C.A. Reule, and W.C. Bausch. 2006. Nitrogen and tillage effects on irrigated continuous corn yields. Agronomy Journal 98(1):63-71.

Hubbs, M.D., M.L. Norfleet, and D.T. Lightle. 2002. Interpreting the soil conditioning index. In Making Conservation Tillage Conventional: Building a Future on 25 Years of Research, ed. E.V. Santen, 192-196. Proceedings of 25th annual southern conservation tillage conference for sustainable agriculture. Special Report No. 1.Alabama Agricultural Experiment Station and Auburn University.

Karlen, D.L., M.J. Mausbach, J.W. Doran, R.G. Cline, R.F. Harris, and G.E. Schuman. 1997. Soil quality: A concept, definition, and framework for evaluation. Soil Science Society of America Journal 61(1):4-10.

Karlen, D.L., E.C. Hurley, S.S. Andrews, C.A. Cambardella, D.W. Meek, M.D. Duffy, and A.P. Mallarino. 2006. Crop rotation effects on soil quality at three northern corn/soybean belt locations. Agronomy Journal 98(3):484-495.

Mosier, A.R., A.D. Halvorson, C.A. Reule, and X.J. Liu. 2006. Net global warming potential and greenhouse gas intensity in irrigated cropping systems in northeastern Colorado. Journal of Environmental Quality 35(4):1584-1598.

SAS Institute. 2002. The SAS system for Windows, version 9.1. SAS Inst., Cary, NC.

Sherrod, L.A., G. Dunn, G.A. Peterson, and R.L. Kolberg. 2002. Inorganic carbon analysis by modified pressurecalcimeter method. Soil Science Society of America Journal 66(1):299-305.

Sojka, R.E., and D.R. Upchurch. 1999. Reservations regarding the soil quality concept. Soil Science Society of America Journal 63(5):1039-1054.

Sporcic, M.,T. Keep, and L. Nelson. 1998.WEQ Management Period Method Wind Erosion Model Worksheet. http:// www.nm.nrcs.usda.gov/technical/tech-notes/agro/ ag55.xls.

Tabatabai, M.A. 1994. Soil enzymes. In Methods of Soil Analysis: Microbiological and Biochemical Properties. Part 2, ed. R.W. Weaver, et al., Soil Science Society of America Book Serial 5. Madison, WI: Soil Science Society of America.

USDA NRCS (Natural Resources Conservation Service). 2002. Soil conditioning index for cropland management systems. NRCS National Agronomy Manual, Directive No. 190-V-NAM. http://policy.nrcs.usda.gov/media/ pdf/M_190_NAM.pdf.
USDA NRCS. 2003. Interpreting the soil conditioning index: A tool for measuring soil organic matter trends. Soil Quality-Agronomy Tech. Note No. 16. http://soils. usda.gov/sqi/concepts/soil_organic_matter/som_sci. html.

USDA NRCS. 2007a. Soil Management Assessment Framework. http://soilquality.org/tools/smaf_intro. html.

USDA NRCS. 2007b. Soil Tillage Intensity Rating Help. http://stir.nrcs.usda.gov/DefaultHelp.aspx\#Purpose.

Vance, E.D., P.C. Brookes, and D.S. Jenkinson. 1987. An extraction method for measuring microbial biomass C. Soil Biology and Biochemistry 19(6):703-707.

Wienhold, B.J., J.L. Pikul, M.A. Liebig, M.M. Mikha, G.E. Varvel, and J.W. Doran. 2006. Cropping systems effects on soil quality in the Great Plains: Synthesis from a regional project. Renewable Agriculture and Food Systems 21(1):49-59.

Woodruff, N.P., and F.H. Siddoway. 1965. A wind erosion equation. Soil Science Society of America Proceedings 29(5):602-608

Zobeck, T.M., J. Crownover, M. Dollar, R.S. Van Pelt, V. Acosta-Martinez, K.F. Bronson, and D.R. Upchurch. 2007. Investigation of soil conditioning index values for southern High Plains agroecosystems. Journal of Soil and Water Conservation 62(6):433-442. 